\title{
The impact of intensive sheep grazing in the spring on the vegetation of xerothermic grasslands in Stawska Góra nature reserve
}

\author{
Marianna Warda $^{1 *}$, Mariusz Kulik ${ }^{1}$, Tomasz Gruszecki ${ }^{2}$ \\ ${ }^{1}$ Department of Grassland and Landscape Forming, University of Life Sciences in Lublin, Akademicka 15, 20-950 \\ Lublin, Poland, *e-mail: marianna.warda@up.lublin.pl \\ ${ }^{2}$ Department of Small Ruminant Breeding and Agricultural Advisory, University of Life Sciences in Lublin, \\ Akademicka 15, 20-950 Lublin, Poland
}

\begin{abstract}
The aim of study was to assess the impact of intensive sheep grazing in the spring on the vegetation of xerothermic grasslands in Stawska Góra nature reserve, particularly the Carlina onopordifolia seedling development and preferences concerning the ingestion of specific plant species, including shrubs and tree-understory. In May 2015, 40 specimens of the Świniarka Sheep and Polish Lowland Sheep were grazed in an area of 1.85 ha. Phytosociological relevés were taken using the Braun-Blanquet method. Changes in the plant cover were assessed in July 2015 under grazing and non-grazing conditions. The flowery grassland plants were assigned to the Cirsio-Brachypodion pinnati alliance and thicket communities - to the Rhamno-Prunetea class. There was confirmed that community under study is distinguished by a large share of Carlina onopordifolia. The number of Carlina onopordifolia seedlings in the grazed areas was significantly greater than in the non-grazed areas. The sheep ingested all herbaceous plants appearing in the grasslands in May, except for the poisonous Adonis vernalis and most of shrubs. Preliminary research results indicate that grazing in the spring led to a decreased cover-abundance of Brachypodium pinnatum and some shrubs, and also - to smaller share of dead organic matter in the plant cover. It can create favourable conditions for the generative reproduction of xerothermic plants such as Carlina onopordifolia.
\end{abstract}

Key words: active protection, Carlina onopordifolia, Nature 2000 site, succession, syntaxonomy, Volhynian Polesie region.

\section{Introduction}

Calcareous xerothermic grasslands of the Festuco-Brometea class are semi-natural communities formed as a result of long-lasting agricultural land use. They usually cover small tracts of land and occur throughout Poland, particularly in the south of the country and in the Lublin Upland. Generally these areas are rarely used today for agricultural purposes. Xerothermic grasslands are dominated by steppe plants accompanied by meadow and scrub species, while calcium carbonate-rich soils constitute the substrate (Fijałkowski \& Izdebski 1957). Well-developed xerothermic plant communities are a sanctuary for rare and endangered species, but abandoning the use of these grasslands leads to undesirable habitat changes that pose a threat to the per- sistence of the protected and characteristic plant species (Bornkamm 2006; Barańska et al. 2010). The cutting of xerothermic grasslands is merely a substitute for proper use and does not ensure the appropriate development of these plant communities (Bąba 2003, 2004).

In the past, cattle or sheep grazing was seen as harmful to grasslands (Fijałkowski 1959). Today, it is believed that the biggest threats to xerothermic grasslands include the lack of grazing, biocenotic evolution and accumulation of dead organic matter, which leads to succession changes in the natural habitat (Kulik et al. 2015). These changes result in the development of Rhamno-Prunetea thickets and smaller floristic diversity of communities (Loster \& Gawroński 2005; Babczyńska-Sendek et al. 2010). The medium-rank threats include problematic native species 
(mainly Brachypodium pinnatum) whose increased occurrence results from the lack of grazing (Kulik et al. 2015). Some areas of xerothermic grasslands are protected within nature reserves (e.g. Stawska Góra), environmental use areas or constitute a Natura 2000 habitat protected by the Habitats Directive, but they are disappearing at a fast pace because they are not being used or actively managed for preservation purposes (Barańska et. al. 2010). Earlier research results indicate that introducing extensive grazing, particularly of small ruminants, has a positive effect on the improvement of the parameters of such habitats (Krasicka-Korczyńska \& Stosik 2010; Bernacka et al. 2011; Warda \& Kulik 2012; Barańska 2013; Kulik et al. 2013). Stawska Góra nature reserve, one of the most valuable xerothermic plant habitats, is also subject to progressive succession processes (Barańska et al. 2013). This is why its protection status had to be changed from strict to partial in order to enable radical protective measures.

The study objective was to determine the impact of sheep grazing in the spring on the vegetation of xerothermic grasslands in Stawska Góra nature reserve, particularly the Carlina onopordifolia seedling development and preferences concerning the ingestion of specific plant species, including shrubs and tree-understory.

\section{Study area}

Stawska Góra is both a flora reserve and a Natura 2000 area (PLH 060018), and constitutes a unique sanctuary for many rare, relict plant and animal species. On its area has been identified up to 216 species of vascular plants. Among these plants, 30 belongs to a rare species. The 4.9 ha reserve is located on elevated ground called Góra Czubat$\mathrm{ka}$, about $8 \mathrm{~km}$ north-west of Chełm and $1.5 \mathrm{~km}$ north of the Staw village (Barańska et al. 2010). According to the physiographic division, Stawska Góra lies in the Chełm Hills mesoregion that belongs to the Volhynian Polesie region (Kondracki 2009). Stawska Góra nature reserve was established in 1956 to protect the natural steppe vegetation communities (habitat 6210-3 Flowery xerothermic grasslands of the Cirsio-Brachypodion pinnati alliance, Festuco-Brometea class) with rare plant species, including Carlina onopordifolia. In Poland, Carlina onopordifolia is found (four sites) in the Lublin and Małopolska plateau. The extent of its occurrence in Poland is $500 \mathrm{~km}^{2}$, but the populations are very isolated from each other and therefore severely fragmented (Melnyk 2013).

Stawska Góra is one of the few known sites in Poland for Carlina onopordifolia, a Natura 2000 species (2249) (Barańska et al. 2010). The species is listed on Annex II of the Habitats Directive and under Appendix I of the Convention on the Conservation of European Wildlife and Natural Habitats (Bern Convention). It is included in the
Red Data Books of the Ukraine and of Poland. In European regional assessment (EU 27), the species is assessed as Vulnerable (VU). All the Polish populations of Carlina onopordifolia are protected as well as some Ukrainian populations (Melnyk 2013). The existence of Carlina onopordifolia at Stawska Góra was already noted in 1881 (Karo 1883) and later (Skibiński 1953), whereas the reserve was established in 1956 (Barańska et al. 2010). Secondary succession is the biggest threat for xerothermic grasslands in the nature reserve (Barańska et al. 2013; Cwener \& Chmielewski 2014).

\section{Material and methods}

Studies concerning the plant cover in Stawska Góra nature reserve were conducted in the years 2008-2015. Study areas were selected for analysis based on two transects and relevés taken in 2008, 2010 and in 2015 before sheep grazing using the Braun-Blanquet method (Braun-Blanquet 1964). During a period of 28 days, from 5 May to 1 June 2015, 40 specimens of the Świniarka Sheep and Polish Lowland Sheep were grazed in an area of 1.85 ha, under the project "Preserving the Biodiversity of Grassy Habitats in the Eastern Part of the Lublin Region" (MF EOG no. 520/2014/Wn-03/OP-XN-02/D).

The grazing was conducted in early spring to reduce the share of shrubs that prevail in some areas of the nature reserve and are a threat to xerothermic grasslands. This study presents the results of investigations conducted in 2015. The state of the vegetation under grazing and non-grazing conditions was analysed. Changes in the plant cover were assessed from June to August in 2015 on the plots area of $25 \mathrm{~m}^{2}$ in 3 repetitions. The persistence of occurrence and cover-abundance by characteristic species, particularly Carlina onopordifolia, presence of protected species (Regulation of the Minister of the Environment... 2014) and expansive species (Brachypodium pinnatum), the shrub layer abundance and dead organic matter were analysed. Carlina onopordifolia seedlings were counted in August 2015 in four repetitions in plots of $6.25 \mathrm{~m}^{2}$ where an insignificantly varied number of specimens in bloom were found in the previous year. Counting of particular specimens was performed on selected plots which characterized by a cover-abundance score of 3 (25-50\%) according to the Braun-Blanquet scale. The obtained number of C. onopordifolia seedlings in 4 repetitions were subjected to the ANOVA analysis complemented by the Tukey test $(p<0.05)$. Furthermore, the nutritional preferences of the sheep were assessed in relation to the plant species occurring in the grasslands. The vascular plant nomenclature according to Mirek et al. (2002), and the classification of communities according to Matuszkiewicz (2008) were used. 


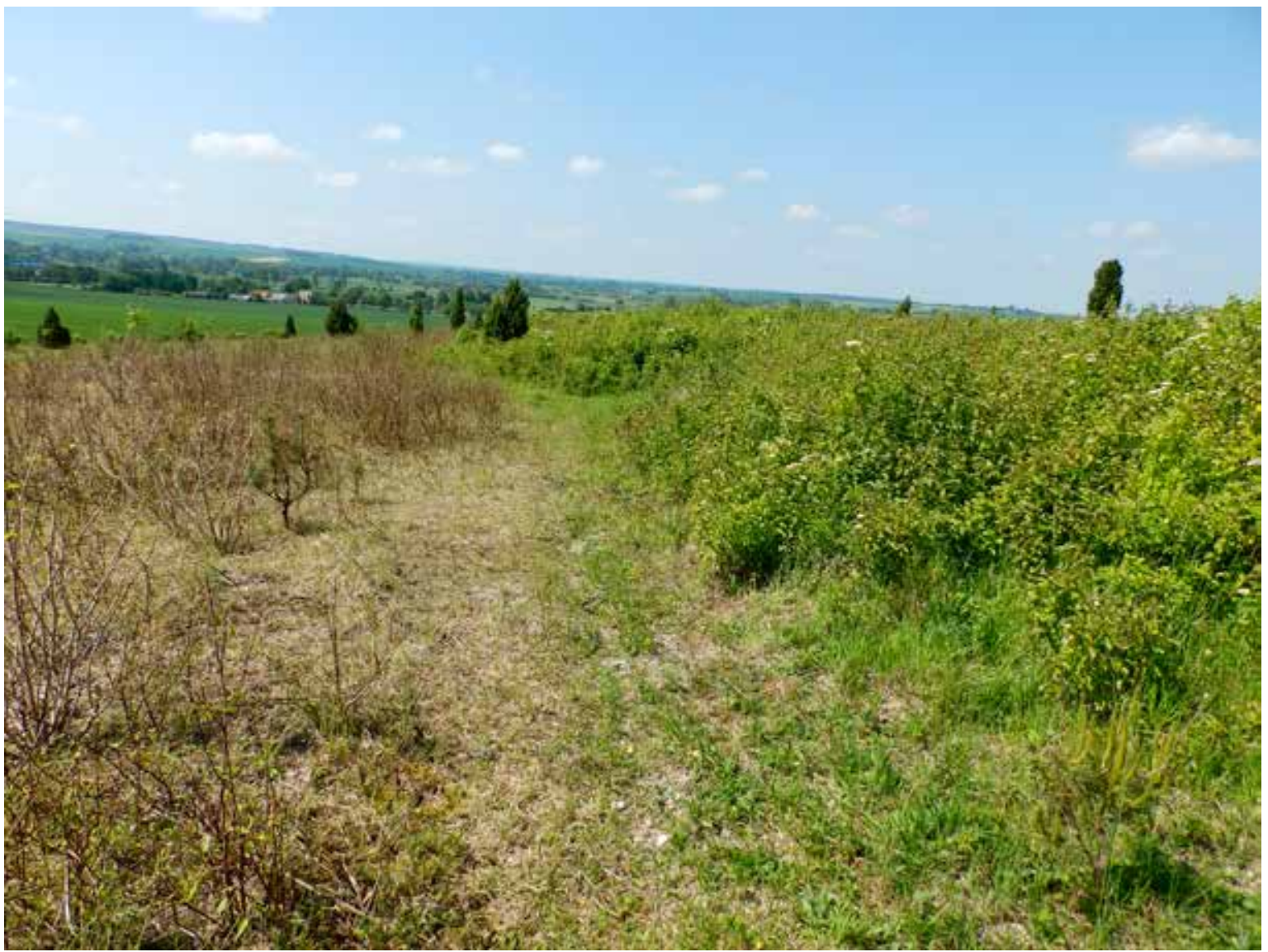

Figure 1. Selected grassland area with and without grazing in Stawska Góra nature reserve, 1/06/2015

\section{Results and discussion}

Based on the analysis of phytosociological relevés taken within Stawska Góra nature reserve, the flowery grassland plants were assigned to the Cirsio-Brachypodion pinnati alliance (Table 1).

The community under study is distinguished by a large share of Carlina onopordifolia, a species connected with the Inuletum ensifoliae plant association. According to Barańska et al. (2013), grassland communities in Stawska Góra nature reserve are represented by Inuletum ensifoliae association and community with Brachypodium pinnatum and Teucrium chamaedrys and also initial community with Anemone sylvestris and Aster amellus, established on previously abandoned area. However, it is difficult to place the grassland studied in Inuletum ensifoliae association because Inula ensifolia occurs only in one small patch $\left(1 \mathrm{~m}^{2}\right)$ in the nature reserve. Grądziel (2000), on the other hand, distinguished the Brachypodio-Teucrietum association here (facies with Carlina onopordifolia). The results of studies by Izdebski (1958) show that previously Inula ensifolia also occurred in a small patch but the share of shrubs was much smaller. For several years, the shrub cover on this site has been larger and poses a real threat to this plant (Kulik et al. 2015).

Among rare and protected species, Anemone sylvestris, Carlina onopordifolia and Primula veris are the most numerous; they are local co-dominants in grasslands with a small cover of shrubs, particularly in the northern and south-eastern part of the nature reserve (Kulik et al. 2015). According to the latest monitoring data, the Carlina onopordifolia population consisted of about 5,100 specimens (GIOŚ 2013). Although studies conducted in 2015 confirmed the stability of the Carlina onopordifolia population (4,000-5,000 plants) in Stawska Góra nature reserve, particular attention should be paid to protecting this species as it occurs on so few sites (Kulik et al. 2015).

The sheep ingested all herbaceous plants appearing in the grasslands in May, except for the poisonous Adonis vernalis and most of shrubs (Fig. 1). Juniperus communis i Pinus sylvestris were ingested by sheep to a small extent.

Furthermore, the sheep nibbled Carlina onopordifolia although according to some authors (Barańska et al. 2013), these animals ignore plants with a xerothermic structure. It should be added, however, that the grazing in Stawska Góra reserve took place in May, in the early development 


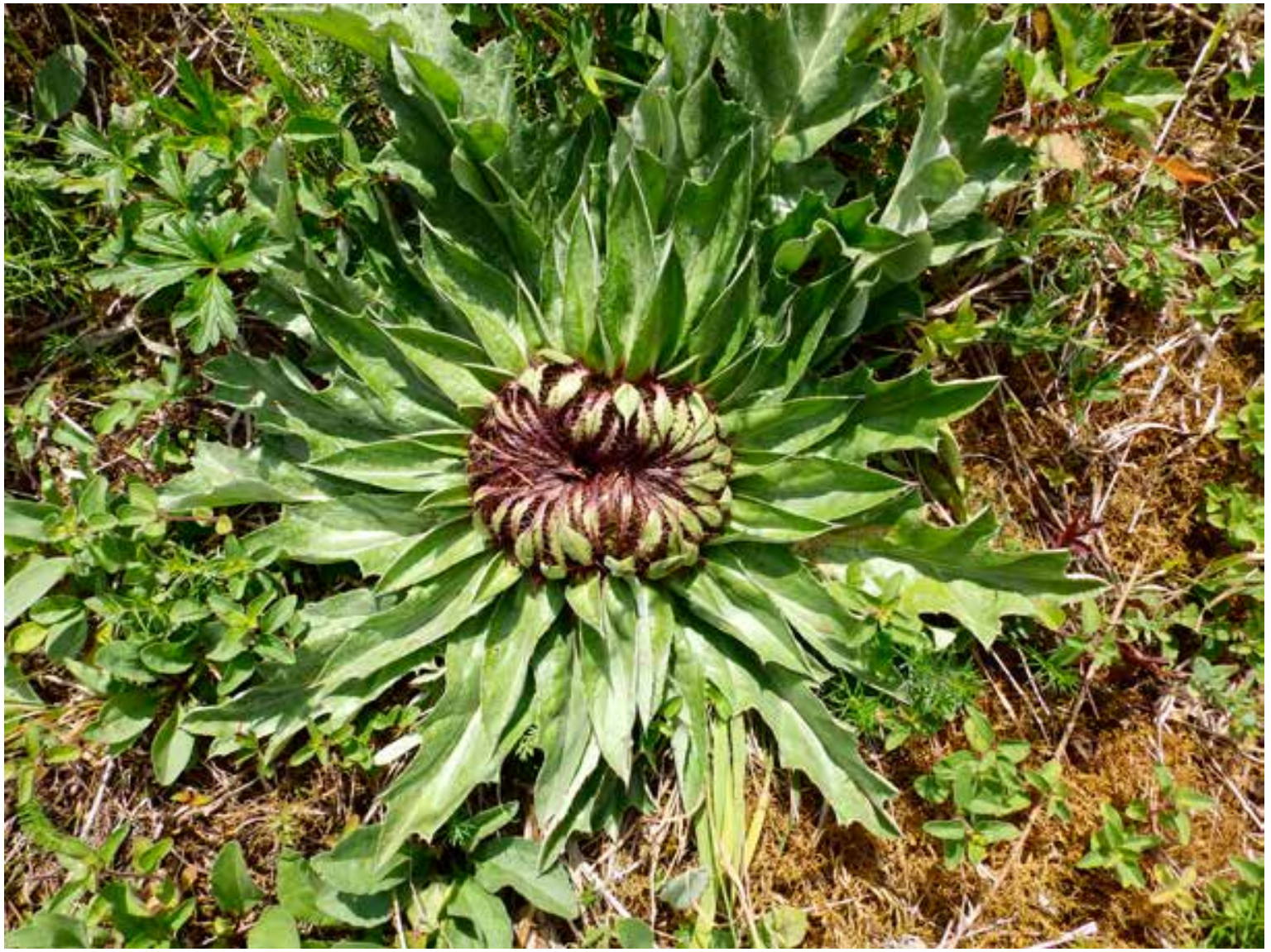

Figure 2. Carlina onopordifolia specimen after grazing, Stawska Góra nature reserve, 16/07/2015

phase when vegetation, including Carlina onopordifolia, was not lignified yet. Specimens that bloomed in 2015 and were nibbled by the sheep but had deformed inflorescences and leaves shorter by $50-70 \%$ in comparison with specimens that were not nibbled (Fig. 2).

Thicket communities of the Rhamno-Prunetea class mainly occur in the southern part of the nature reserve where they form a mosaic with xerothermic grasslands. These communities are dominated by shrubs such as Cornus sanguinea, Viburnum opulus, Prunus spinosa and Rhamnus catharticus, with a smaller share of Prunus fruticosa, Juniperus communis, Rosa canina, Frangula alnus, Pinus sylvestris, Prunus avium, Pyrus communis and Rubus caesius and herbaceous plants: Salvia pratensis, Anemone sylvestris, Valeriana angustifolia, Galium mollugo and Pimpinella saxifraga (Table 1).

Preliminary research results indicate that grazing in the spring led to a decreased cover-abundance of Brachypodium pinnatum and shrubs (Table 2) up to $50 \mathrm{~cm}$ high such as Cornus sanguinea, Frangula alnus, Prunus spinosa and Viburnum opulus), but only within the xerothermic grassland. This parameter did not improve in the patch dominated by shrubs (Kulik et al. 2015). A smaller share of dead organic matter in the plant cover was also found after the grazing. The improvement of this parameter and the decreased cover-abundance of shrubs can create favourable conditions for the generative reproduction of xerothermic plants such as Carlina onopordifolia. Since Carlina onopordifolia reproduces exclusively from seeds, the yielding of fertile seeds and suitable conditions for their germination are essential. However, under natural conditions only $20 \%$ of seeds can germinate and the amount of new seedlings is not so much as it could be inferred from reproductive potential (Poznańska 1991a). Furthermore, seeds of Carlina onopordifolia are heavy and therefore their dispersal is hampered (Poznańska 1991b). Seeds can germinate on open soil, i.e. on sites where grazing eliminates dead organic matter. This confirms that domestic animals grazing is the right method of protecting xerothermic grasslands as well as eliminating other threats to these habitats and increasing the flora and fauna diversity (Bernacka et al. 2011; Barańska et al. 2013).

The ratio of Carlina onopordifolia specimens in the particular development phases was 9:19:11:1, regardless of the use type (Table 3). 
Table 1. Phytosociological description of xerothermic grasslands (selected syntaxonomical groups), protected species and nutritional preferences of the sheep in Stawska Góra nature reserve, 2015

\begin{tabular}{|c|c|c|c|c|}
\hline Characteristic & Stability & Cover abundance & Protected species & Ingestion preference \\
\hline \multicolumn{5}{|l|}{ ChAll. Cirsio-Brachypodion pinnati } \\
\hline Aster amellus & $\mathrm{V}$ & 1194 & $S$ & 4 \\
\hline Melampyrum arvense & $\mathrm{V}$ & 653 & - & 4 \\
\hline Carlina onopordifolia * & IV & 1820 & $\mathrm{~S}$ & 4 \\
\hline Asperula tinctoria & II & 128 & $\mathrm{~V}$ & 4 \\
\hline Campanula sibirica & II & 137 & $\mathrm{~S}$ & 4 \\
\hline Carex flacca & $\mathrm{I}$ & 146 & - & 4 \\
\hline Elymus hispidus & I & 78 & $\mathrm{R}$ & 4 \\
\hline \multicolumn{5}{|l|}{ ChO. Festucetalia valesiacae } \\
\hline Salvia verticillata & IV & 339 & - & 4 \\
\hline Scabiosa ochroleuca & IV & 625 & - & 4 \\
\hline Achillea collina & III & 1111 & - & 4 \\
\hline Astragalus onobrychis & II & 86 & - & 4 \\
\hline Potentilla arenaria & II & 17 & - & 4 \\
\hline Adonis vernalis & $\mathrm{I}$ & 83 & $\mathrm{~S}, \mathrm{~V}$ & 0 \\
\hline Thesium linophyllon & I & 347 & - & 4 \\
\hline \multicolumn{5}{|l|}{ ChCl. Festuco-Brometea } \\
\hline Euphorbia cyparissias & $\mathrm{V}$ & 642 & - & 4 \\
\hline Anthyllis vulneraria & IV & 86 & - & 4 \\
\hline Asperula cynanchica & IV & 989 & - & $\mathrm{X}$ \\
\hline Brachypodium pinnatum & IV & 172 & - & 4 \\
\hline Carlina vulgaris & IV & 64 & - & 4 \\
\hline Galium album & IV & 156 & - & 4 \\
\hline Onobrychis viciifolia & IV & 269 & - & 4 \\
\hline Salvia pratensis & IV & 203 & - & 4 \\
\hline Teucrium chamaedrys & IV & 81 & - & 4 \\
\hline Centaurea scabiosa & III & 61 & - & 4 \\
\hline Dianthus carthusianorum & III & 28 & - & 4 \\
\hline Allium oleraceum & II & 8 & - & 4 \\
\hline Campanula glomerata & $\mathrm{I}$ & 28 & - & 4 \\
\hline Gentiana cruciata & I & 14 & $S$ & 4 \\
\hline Poa compressa & I & 642 & - & 4 \\
\hline \multicolumn{5}{|l|}{ Shrubs } \\
\hline Prunus spinosa & $\mathrm{V}$ & 1194 & - & 3 \\
\hline Viburnum opulus & $\mathrm{V}$ & 653 & - & 4 \\
\hline Cornus sanguinea & IV & 1820 & - & 4 \\
\hline Frangula alnus & III & 128 & - & 4 \\
\hline Juniperus communis & III & 137 & - & 2 \\
\hline Pyrus communis & III & 146 & - & 2 \\
\hline Rosa canina & III & 78 & - & 2 \\
\hline Rubus caesius & III & 183 & - & 2 \\
\hline Chamaecytisus ruthenicus & II & 197 & - & 3 \\
\hline Pinus sylvestris & II & 103 & - & 1 \\
\hline Rhamnus catharticus & II & 36 & - & 4 \\
\hline Prunus avium & $\mathrm{I}$ & 3 & - & $\mathrm{X}$ \\
\hline Prunus fruticosa & $\mathrm{I}$ & 3 & - & $\mathrm{X}$ \\
\hline Range number of species in relevés & & & $18-61$ & \\
\hline
\end{tabular}

Abbreviations:

Protected species: * - species of Community importance, requires the designation of Natura 2000 site; S - strict protecion; Polish Red List of Plants: $\mathrm{V}$ - vulnerable to extinction; $\mathrm{R}$ - rare potentially threatened to extinction.

Ingestion preference: 4 - very willingly ingested (utilization 90-100\%); 3 - willingly ingested (utilization 50-90\%); 2 - nibbled to a small extent (utilization $10-50 \%$ ); 1 - nibbled to a very small extent (utilization $<10 \%$ ); 0 - not nibbled at all; $\mathrm{X}-$ not found in the area of grazing. 
Table 2. Mean plant cover, Brachypodium pinnatum content, shrub density and dead organic matter (\%), Stawska Góra nature reserve, 2015

\begin{tabular}{|l|c|c|c|}
\hline \multirow{2}{*}{ Characteristic } & \multicolumn{2}{|c|}{ Grazing } & \multirow{2}{*}{$\begin{array}{c}\text { Without } \\
\text { grazing }\end{array}$} \\
\cline { 2 - 3 } & before & after & 95 \\
\hline Plant cover & 92 & 79 & 17 \\
\hline Brachypodium pinnatum & 17 & 10 & 38 \\
\hline Shrub`s density & 40 & 28 & 12 \\
\hline Dead organic matter & 12 & 2 & \\
\hline
\end{tabular}

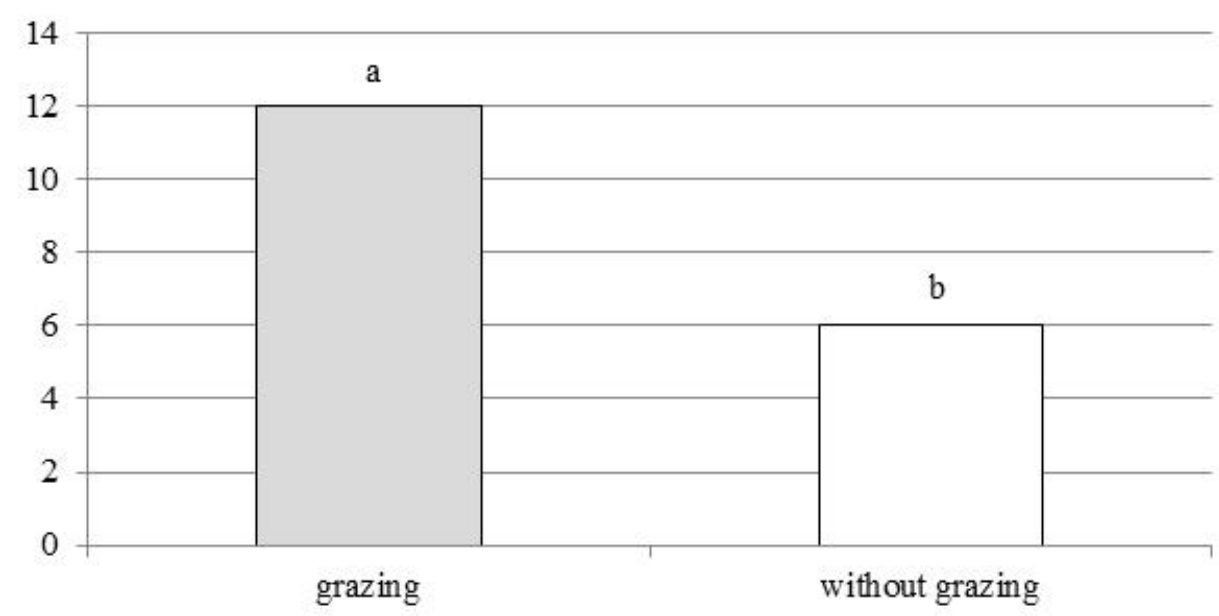

Figure 3. The mean number of Carlina onopordifolia seedlings, Stawska Góra nature reserve, 2015 (abbreviations: $\mathrm{a}, \mathrm{b}-$ different letters mean significant differences; $\mathrm{p}<0.05$ )

According to Cwener and Chmielewski (2014), the age structure of the Carlina onopordifolia population in Stawska Góra nature reserve is stable. The authors established that the ratio of specimens in the particular development phases was 9:10:5:1. The ratio of specimens in the present study was greater because the selected patches had a cover-abundance score of $3(25-50 \%)$ according to the Braun-Blanquet scale.

The number of seedlings of Carlina onopordifolia that appeared in the study plots during the 2015 growing season depended on the grazing of sheep in May and in the grazed areas was significantly greater than in the non-grazed areas (Fig. 3).

The study does not provide data on the impact of grazing on development phases other than the seedling phases because the lifespan of Carlina onopordifolia is 20 years. This is a monocarpic species that dies down after flowering and seed development - the number of individuals per year fluctuates naturally (Denisiuk et al. 2009). Therefore, the impact of grazing on the other development phases should be conducted for at least 20 years.

\begin{tabular}{|l|c|c|}
\hline \multicolumn{1}{|c|}{ Development phase } & Number of leaves & $\begin{array}{c}\text { The mean number } \\
\text { of specimens }\end{array}$ \\
\hline seedlings & 2 & 9 \\
\hline juvenile specimens & $3-4$ & 19 \\
\hline vegetative specimens & $>5$ & 11 \\
\hline flowering & - & 1 \\
\hline
\end{tabular}

Table 3. The number of Carlina onopordifolia specimens depending on development phase, Stawska Góra nature reserve, 2015 
Barańska K., 2013, Best practices manual for protection of xerothermic grasslands, www.lasy.gov.pl.

Barańska K., Chmielewski P., Cwener A. \& Pluciński P., 2010, Conservation and restoration of xerothermic grasslands in Poland - theory and practice, Wydawnictwo Klubu Przyrodników, Świebodzin: 1-48.

Barańska K., Żmihorski M. \& Pluciński P., 2013, Raport z projektu Ochrona muraw kserotermicznych w Polsce teoria i praktyka LIFE08 NAT/PL/513 [Project report Conservation of xerothermic grasslands in Poland - theory and practice LIFE08 NAT/PL/513], Wydawnictwo Klubu Przyrodników, Świebodzin: 1-109.

Bąba W., 2003, Changes in the structure and floristic composition of the limestone grasslands after cutting trees and shrubs and mowing, Acta Soc. Bot. Poloniae 1(72): 61-69.

Bąba W., 2004, The species composition and dynamics in well-preserved and restored calcareous xerothermic grasslands (South Poland), Biologia, 59(4): 447-456.

Bernacka H., Simińska E. \& Niedźwiecki P., 2011, The alternative methods of using sheep, Wiad. Zootechniczne 49(3): 59-66.

Bornkamm R., 2006, Fifty years vegetation development of a xerothermic calcareous grassland in Central Europe after heavy disturbance, Flora 201: 249-267.

Braun-Blanquet J., 1964, Pflanzensoziologie. Grundzüge der Vegetationskunde [Plant sociology. The study of plant communities], 3rd ed., Springer Publ., Wien-New York.

Cwener A. \& Chmielewski P., 2014, Dokumentacja Planu Zadań Ochronnych obszaru Natura 2000 PLH060018 STAWSKA GÓRA w województwie lubelskim [Documentation of Conservation Measures Plan for Natura 2000 area PLH060018 STAWSKA GÓRA in Lubelskie Province], RDOŚ, Lublin: 1- 51.

Denisiuk Z., Chmura D. \& Adamski P., 2009, Flowering and generative reproduction in isolated populations of endangered species Carlina onopordifolia Besser (Asteraceae) in Poland, Pol. J. Ecol. 57(1): 89-97.

Fijałkowski D.\& Izdebski K., 1957, Steppe communities of the Lublin Upland, Annales UMCS, B, 12: 167-199.

Fijałkowski D., 1959, Drugie stanowisko dziewięćsiłu popłocholistnego (Carlina onopordifolia Bess.) na Wyżynie Lubelskiej [The second place of Carlina onopordifolia occurrence in the Lublin Upland], Chrońmy Przyr. Ojczystą 15(2): 16-19.

GIOŚ, 2013, Dziewięćsił popłocholistny Carlina onopordifolia (2249). Monitoring gatunków i siedlisk przyrodniczych ze szczególnym uwzględnieniem specjalnych obszarów ochrony siedlisk Natura 2000 [Monitoring of species and habitats with particular emphasis on special areas Natura 2000 habitats protection], Inspekcja Ochrony Środowiska, Warszawa: 1-14.
Grądziel T., 2000, Charakterystyka geobotaniczna powierzchni objętych badaniami entomologicznymi [Geobotanical characteristics of the surface under entomological study], [in:] J. Lętowski (ed.), Walory przyrodnicze Chełmskiego Parku Krajobrazowego i jego najbliższych okolic [The natural values Chełmski Landscape Park and the surrounding area], Wyd. UMCS. Lublin: 89-105.

Izdebski K., 1958, Badania fitosocjologiczne i florystyczne w rezerwacie Stawska Góra pod Chełmem [Phytosociological and floristic studies in the Stawska Góra reserve near Chełm], Ann. UMCS, C, 13: 213-230.

Karo F., 1883, Spis rzadszych krajowych roślin zebranych w latach 1881 i 1882 w okolicach Lublina, oraz pod Stawską górą za Chełmem [List of national rare plants collected in 1881 and 1882 near Lublin and the Stawska Mt near Chełm], Pam. Fizjograf. 3: 292-317.

Kondracki J., 2009, Geografia regionalna Polski [Regional geography of Poland], PWN, Warszawa.

Krasicka-Korczyńska E. \& Stosik T., 2010, Wpływ oddziaływań zooantropogenicznych na roślinność muraw kserotermicznych [The influence of zoo-anthropogenic impact on the xerothermic grasslands vegetation], [in:] H. Ratyńska, B. Waldon (eds), Ciepłolubne murawy w Polsce - stan zachowania i perspektywy ochrony [Thermophilous grasslands in Poland - state of preservation and protection perspectives], Wyd. Uniw. Kazimierza Wielkiego, Bydgoszcz: 80-94

Kulik M., Warda M. \& Leśniewska P., 2013, Monitoring the diversity of psammophilous grassland communities in the Kózki Nature Reserve under grazing and nongrazing conditions, Journal of Water and Land Development 19 (VII-XII): 59-67.

Kulik M., Warda M., Gruszecki T., Tatarczak M. \& Patkowski K., 2015, Ocena zagrożeń i metod ochrony muraw kserotermicznych z klasy Festuco-Brometea w rezerwacie przyrody Stawska Góra [Assessment of threats and protection methods of xerothermic grasslands of Festuco-Brometea class in Stawska Góra nature reserve], Łąkarstwo w Polsce 18: 145-157.

Loster S. \& Gawroński S., 2005, Przemiany nawapiennej murawy w rezerwacie „Biała Góra” (Wyżyna Miechowska, południowa Polska) w ciągu ostatnich 80 lat [Changes in a calcareous grassland in the reserve "Biała Góra" (Miechowska Upland, S Poland) during the last 80 years], Fragmenta Floristica et Geobotanica Polonica 12: 301-315.

Matuszkiewicz W., 2008, Przewodnik do oznaczania zbiorowisk roślinnych [Guidebook of plant communities], Wyd. PWN, Warszawa.

Melnyk V., 2013, Carlina onopordifolia. The IUCN Red List of Threatened Species 2013, e.T161848A5503822, htpp://dx.doi.org/10.2305/IUCN.UK.20111.RLTS. T161848A5503822.en. 
Mirek Z., Piękoś-Mirkowa A., Zając A. \& Zając M., 2002, Flowering plants and pteridophytes of Poland. A checklist, [in:] Z. Mirek (ed.), Biodiversity of Poland, W. Szafer Institute of Botany, Polish Academy of Sciences, Kraków, 1: 1-442.

Poznańska Z., 1991a, Carlina onopordifolia Besser - the dynamics of its population in the course of succession of xerothermal swards and the problem of active ecological protection, Ochrona Przyr. 48: 55-83.

Poznańska Z., 1991b, Zmiany zagęszczenia i struktury populacji dziewięćsiła popłocholistnego Carlina onopordifolia Besser w procesie sukcesji murawy kserotermicznej oraz problemy jego aktywnej ochrony "in situ" [The changes in concentration and structure of Carlina onopordifolia Besser due the process of succession of xerothermic grasslands and the problems of its active protection ,in situ”], Prądnik, Prace Muz. Szafera 3: 161-174.
Rozporządzenie Ministra Środowiska z dnia 9.10.2014 r. o ochronie gatunkowej roślin (Dz.U. RP 2014, poz. 1409) [Regulation of the Minister of the Environment of 9 October 2014 on the species-specific protection of plants (Dz. U. RP [Journal of Laws RP] 2014, item 1409)], 2014, Kanc. Prezesa Rady Min., Warszawa.

Skibiński S., 1953, Rezerwat dziewięćsiłu popłocholistnego na Stawskiej Górze [Carlina onopordifolia reserve in Stawska Góra], Chrońmy Przyr. Ojcz. 3: 33-37.

Warda M. \& Kulik M., 2012, Szata roślinna muraw w rezerwacie „Kózki” w warunkach wypasu owiec rasy świniarka [The vegetation of grasslands in the Kózki nature reserve under conditions of grazing by the Świniarka sheep], [in:] T. Gruszecki (ed.), Czynna ochrona wybranych siedlisk Natura 2000 z wykorzystaniem rodzimych ras owiec [Active protection of selected Natura 2000 habitats using native breeds of sheep], Wyd. Uniw. Przyrodniczego, Lublin: 29-43. 